\title{
KOLONIALE VRAAGSTUKKEN TEN OPZICHTE VAN ONZE WEST ANDERHALVE EEUW GELEDEN
}

\author{
I \\ DOOR
}

\section{A. HALLEMA}

In den eersten jaargang van De West-Indische Gids (dl. I, blz. 441 e.v.) heeft een opstel gestaan „Curaçao tegen het einde der West-Indische compagnie", waarin , voor zoover het genoemde eiland betreft, mededeeling wordt gedaan van den inhoud van het rapport der commissarissen Grovestins en De Boey, dat zich in afschrift op het Rijksarchief bevindt. De voorgeschiedenis van de uitzending dezer commissarissen is belangrijk genoeg om ook daarvan een en ander mee te deelen.

Het is algemeen bekend, dat de vierde Engelsche oorlog (1780 -'84) aan de reeds lang in verval verkeerende West-Indische Compagnie van 1674 den doodsteek heeft bezorgd en haar liquidatie in 1792, toen de Staat haar bezittingen en schulden overnam op de basis van $30 \%$ der nominale waarde van de acties der participanten bij wijze van schadeloosstelling, was dus nog slechts een kwestie van tijd, een proces van slooping en algeheele afbraak, verdeeld over een tiental jaren. Maar toch is die laatste bestaansperiode der W.I.C. in zooverre een merkwaardige periode, dat er in den boezem der geheel vervallen handelsmaatschappij nog gehoopt werd op een bijzonder ingrijpen van Prins Willem V, na de restauratie zijner dynastie in 1787 niet alleen opnieuw erkend stadhouder der Republiek doch ook als erfelijk opperbewindhebber dezer Compagnie. Hij zou het moeten zijn, die de geldzorgen der W.I.C. verlichtte, de eenheid in het bestuur herstelde, vooral ook de verdediging der West-Indische koloniën reorganiseerde overeenkomstig de gewijzigde behoeften en eischen des tijds, de justitie op een beter basis handhaafde en den handel, speciaal den slavenhandel, tot nieuwen bloei bracht. De uitwer- 
king van al deze programpunten, waarmee het bestaan en vooral de gewenschte herleving der W.I.C. ten nauwste samenhingen, meer, daarvan afhankelijk waren, verwachtte men van den stadhouder, zonder dat het hoofdbestuur dezer maatschappij eigenlijk zelf tot reorganisatie, tot beter koloniaal beheer en vooral tot offers in eigen kring bereid werd gevonden.

Want de koloniale handel was al sedert jaren sterk afgenomen en in zekere zin nimmer van groote beteekenis geweest. De slavenhandel moest het tekort aanvullen van wat in een vorige eeuw de kaapvaart en handel in krijgsmaterialen had gedaan. De tweede W.I.C. diende zich immers aan als koloniaal bestuursorgaan, niet als handelsmaatschappij met solide waarborg tot winstgevende geldbelegging in haar aandeelen. Zeer juist is eens door Mr. Dr. S. van Brakel opgemerkt, hetgeen wel speciaal voor de laatste bestaansperiode der W.I.C. van toepassing is: „Maar alle kamers zonder onderscheid waren bezield door een eng mercantilistische handelspolitiek, die eischte, dat alle verkeer uitsluitend naar en van het Moederland zou gaan en geen verkeer tusschen de koloniën onderling of met vreemde koloniën toeliet. Hoewel de Compagnie althans op de koloniën geen eigen handel meer dreef, dus niet voor concurrentie behoefde te vreezen, dreef de angst, dat de recognitiegelden haar konden ontgaan haar tot een strenge fiscaliteit. Daarover werd door de vaderlandsche kooplieden wel geklaagd, maar een wezenlijk vrijgeviger handelspolitiek werd ook door hen niet begeerd. Met leede oogen zagen zij de opkomende concurrentie, die vreemde kooplieden hun aandeden, door uit de Deensche en Engelsche koloniën waren binnen te smokkelen en tegen lageren prijs tèverkoopen". Daarnaast eischte de decentralisatie een te zwaar en noodeloos kostbaar bestuursapparaat, een voortdurend geschrijf en gewrijf tusschen de kamers onderling, zonder dat men ooit tot flinke, eenstemmig genomen maatregelen, veel minder tot doeltreffende reorganisatie kon komen, welke des te noodzakelijker werd, toen de lasten telken jare de baten overtroffen, uit de koloniën tal van klachten over slecht bestuur en wanbeheer naar het moederland werden gezonden en de opdringende concurrentie van andere naties den handel der Nederlandsche kooplieden benadeelde en bedreigde.

In den slavenhandel zelf was, moreel gesproken, eenige verbetering gekomen door de Engelsche wet van 1788, welke voorschreef dat voor elken door een slavenhaler vervoerden slaaf een minimale ruimte moest worden gewaarborgd, berekend naar een maximum van 5 slaven op elke 3 ton scheepsruimte voor schepen 
van 150 ton of minder. In grootere schepen mocht op elke ton scheepsruimte één slaaf worden ingeladen, een maatregel van hygiëne en humaniteit, die echter niet eens lang van kracht bleef. Hoezeer deze handel toen overigens nog met den bloei der koloniën ten nauwste verbonden geacht werd, blijkt wel uit het plakkaat van 24 Nov. 1789, door de Staten-Generaal afgekondigd, ingevolge waarvan het koopen en verkoopen van Afrikaansche slaven door dit hoogste bestuurscollege nog sterk werd aangemoedigd onder het volgend motief: „Nademaal den Handel op de West-Indiën een der aanzienlijkste takken uitleverde van het bestaan voor de Ingezeetenen deeser Landen, en het zeeker was, dat zoo lang er geen nieuwe middelen waren uitgedagt, om de Colonien in Westindien van de noodige handen te voorzien tot het verrigten van den Arbeid, de Negerhandel behoorde aangemerkt te worden als onafscheidelijk van den bloey en voorspoed dier Colonien en van de geheele Commercie." Toen het octrooi der 2e W.I.C. in 1730 moest worden vernieuwd, was er dan ook reeds de voorwaarde aan verbonden, om telken jare minstens 2500 slaven in te voeren. Werd daaraan niet voldaan - en meermalen is de Societeit van Suriname in gebreke gebleven - dan werden voor haar rekening de ontbrekenden door particuliere slavenhalers van de kust van Guinea gehaald. Ook bij de verlenging van het octrooi in 1762 werd deze voorwaarde wegens het verplicht leveren van slaven in het contract opgenomen. Evenals het plakkaat van 24 Nov. 1788 was ook de resolutie der Staten-Generaal van 27 Augustus 1788 een middel om de gang van zaken bij de W.I.C. nog wat te rekken, hoezeer Raadpensionaris Mr. Laurens van de Spiegel dan ook had aangestuurd op ontbinding der Compagnie. Heeren Hoogmogenden wilden echter wachten, totdat de termijn van haar octrooi was verstreken, trachtten eerst nog wat te plooien en te schikken, o.m. door het invoeren van enkele verbeteringen van korten duur en de tusschenkomst van den Prins in te roepen, die na 1787 weer het benoemingsrecht kreeg ter aanwijzing van personen voor leidende koloniale functies, en het verstrekken van de meest dringende subsidies ${ }^{1}$ ).

Maar vooral dit laatste was het vullen van een bodemlooze put, want aan de geldbehoefte der W.I.C. was bijna niet meer te voldoen. Om ons uitsluitend te beperken tot hetgeen in 1788 daartoe door de Kamers en uit de kolonie zelf was aangevraagd bij de

1) Zie mijn artikel: De Raadpensionaris Mr. L. P. van de Spiegel en zijn Koloniale politiek jegens de West, in dit tijdschrift, jrg. XIX (1937), blz. 87-106, 161-170, 193-207. 
Staten-Generaal en de Gewestelijke Staten van Holland en Zeeland afzonderlijk, moge hier slechts op de volgende feiten worden gewezen. In een adres, gedateerd 3 April 1788, verzochten de Bewindhebbers der W.I.C. aan de Staten-Generaal, om nu toch eindelijk eens hun houding te willen bepalen en een besluit te nemen inzake alle bij hun college gedurende de laatste drie jaren ingekomen en nog niet afgedane ,,adressen, voordragten en raadplegingen wegens de zaken dier Compagnie". Tot dit verzoek zagen de adressanten zich te meer genoodzaakt in verband met de verschillende ingekomen berichten, dat de politieke, economische en justitieele toestanden op Curaçao nog steeds zeer ongunstig bleven en dringend voorziening behoefden. Directeur Jan Jacob Beaujon (1784-'96) leefde er nog steeds in groote oneenigheid met zijn Raden en verschillende planters, kooplieden en andere ingezetenen van dit eiland, waardoor zelfs ernstige ongeregeldheden waren ontstaan. Wel had eerstgenoemde partij door toegeven en inschikkelijkheid onder pressie van het opperbestuur der W.I.C. in het moederland de kalmte kunnen bevorderen en was de rust langzamerhand weergekeerd, maar reeds wezen donkere wolken aan den politieken hemel er op, dat spoedig een nieuwe twist kon uitbarsten, terwijl het ook in Essequibo en Demerary verre van pais en vree was. In de daaraan voorafgaande jaren 1786 en '87 hadden de Heeren X daarvoor al gewaarschuwd, doch zonder resultaat. Zelf waren hun de handen gebonden door gebrek aan contante middelen en de diverse regeeringscolleges, die niet verantwoord waren met lijdelijk toe te zien, staken niettemin geen hand uit den mouw, om de kolonie uit de moeilijkheden, ontstaan door den afgeloopen Engelschen zee-oorlog, te helpen.

Was de aanhef van dit stuk al vrij scherp en veroordeelend van de zijde der partij, die nota bene om raad en financieelen bijstand vroeg, het was zeker simplistisch en onoprecht, om de naderende catastrophe met de W.I.C. uitsluitend te wijten aan de rampzalige gevolgen van den Engelschen zee-oorlog. Het kwaad school dieper en was van jaren her aangewassen tot een reeks van ongerechtigheden, welke bijna niet meer goed gemaakt konden worden. Intusschen verscholen dezelfde Bewindhebbers zich weer achter de toenmalige Regeering des lands door te verklaren, dat zij onder deze omstandigheden den kolonisten geen hulp en verdediging tegen vreemde indringers konden bieden, dat zij buiten staat waren om recht en veiligheid van persoon en goederen te handhaven en de belangen van kolonie en kolonisten konden behartigen, zoolang afdoende hulp en verbetering van de zijde der Staten-Gene- 
raal achterwege bleven. Zooals het er nu in West-Indië toeging, zou het met handel en andere welvaartsbronnen steeds slechter worden en ging de kolonie met rassche schreden haar ondergang tegemoet en daarom moest er wat gedaan worden. Snel handelen kon misschien nog het ergste, dat dreigde, voorkomen, doch dan moest ook citissime worden ingegrepen, desnoods met uitsnijding der zieke plekken uit het zoo ongezonde lichaam der kolonie. Hoe triest de Bewindhebbers den toestand wel niet afschilderden, blijkt het best uit hun eigen woorden, hier even aan te halen, en dan nog is daarop van toepassing het bekende bijbelwoord: de helft is U niet aangezegd! duidelijk voor ieder, die met de geschiedenis der Westindische koloniën na 1780 eenigermate op de hoogte is.

Met bijzonderen aandrang en allen ernst met het oog op den precairen toestand, mede door de trage houding der Staten-Generaal geschapen, wezen de Bewindhebbers de leden van dit college op hun koloniale verplichtingen, wijl adressanten zelf ,,rondborstig moesten declareeren volstrekt buiten staat te zijn het gezag en de belangens van Republiek in de Coloniën te maintineeren; dat zij, zelfs op dit oogenblik, naauwlijks hunne dagelijksche Huishouding konden gaande houden, veel min de Maandgelden hunner Amptenaaren en Militie betaalen, of eenige Ververschingen, Vivres of Medicynen 1) na de Coloniën verzenden. Dat hun Hoog Mogenden daar uit ligtlyk zouden bevroeden, dat, bijaldien die Deliberatien niet ras ten einde mogten kunnen gebragt worden, hun Hoog Mog. zich in de noodzaaklijkheid zouden bevinden, zelf provisioneel en hangende de verdere Deliberatien, schikkingen werkstellig te maaken, waardoor de verdere Confusie geweerd wierd, en voorgekomen, dat de Republiek haare Colonien en de voordeelen, dewelke dezelve aan den Lande behooren aan te brengen, geheel en voor altoos verlooren" 2).

Een tijdgenoot bevestigde den ernst van deze impasse aldus. „Hollands breede Raadslag en Besluit strekte zeer om hulp en ondersteuning toe te brengen aan de West-Indische Maatschappij, die noch Geld, noch Crediet hadt; terwijl de Regeering in de Volkplantingen omver geworpen was en de Justitie onwerkzaam ${ }^{3}$ ); waar uit

1) Vooral op de toezending van geneesmiddelen en med ische hulp in anderen vorm had men vanuit West-Indië gedurende de jaren 1781' 88 bij herhaling en met zeer gering resultaat aangedrongen, een omissie, waarover de kolonisten zich met recht beklaagden.

2) Resolutie generaal 29 Jan. en 1 April 1788.

3) Cursiveering van $\mathrm{mij}, \mathrm{H}$. 
voortvloeide een openlijk gedoogde Handel met Vreemdelingen, die de voordeelen genooten, welke voor de Ingezetenen alleen behoorden bewaard te worden. Eene gesteltenis, huns oordeels zoodanig, dat het Moederland, indien de zaaken langer op dien voet voortgingen, gelijk zij spraaken, beter zou doen de Colonien geheel te laaten vaaren en alle de onafmeetbaare Voordeelen derzelven te missen dan 'er langer kosten aan te besteeden, waar van anderen de vrugten plukten".

Het leek dan ook wel, dat Hollands Staten hunnentwege meer interesse toonden voor de belangen der W.I.C. dan de Heeren Hoogmogenden. In eerstbedoeld college was reeds het probleem gesteld van de centralisatie in het bestuur, aangezien de meeste leden, ook zij, die voor Holland zitting hadden in de StatenGeneraal, van oordeel waren, dat het voor het algemeen belang beter en voordeeliger zou zijn, indien alle West-Indische koloniën onder één bestuur werden gebracht. In den toen bestaanden bestuursvorm waren de meeste gebreken ingeslopen als gevolg van de decentraliseerende invloeden in de vijf Kamers en ter oorzake van haar historische samenstelling, die geen rekening hield met de gewijzigde omstandigheden, terwijl bovendien tusschen die Kamers ,geene genoegzaame gemeenschap was uit hoofde van derzelver zeldzaame Bijeenkomsten en by zommige, van welke slegts een schaduw van Bestuur was overgebleven". En vooral daarom werd in het Hollandsche Staten-college geadviseerd „dat het voor het algemeen belang voordeeliger zijn zou, bijaldien alle de Coloniën in de West-Indiën onder één en dezelfde Directie konden gebragt worden."

Maar in dezelfde Staten-vergadering werd het denkbeeld geopperd, of het wel wenschelijk zou zijn, om zoo kort voor het afloopen van het octrooi der Compagnie telkens weer andere schikkingen te maken. Van deze zijde werd betoogd, dat het voorshands beter zou zijn stabilisatie van het bestuur voor te staan, tot zoolang een nieuw octrooi kon worden verleend om dan meteen tot een ingrijpende reorganisatie over te gaan. In elk geval werd in overweging gegeven slechts die veranderingen in het bestuur aan te brengen of voor te stellen, welke geen langer uitstel gedoogden, ,op dat de Souverein de handen mogt vry houden, om naderhand de Regeering van de Colonien en den Handel op dezelve beter in te rigten". Desnoods kon er een commissie worden benoemd, die te onderzoeken had welke veranderingen en verbeteringen in het bestuursapparaat de meest urgente waren. Doch ieder ingewijde wist wel, dat Holland en Zeeland voortdurend 
twistten over de fortificatiën, in de West-Indische kolonie op te richten en vooral over ieders aandeel in de lasten daarvan; dat verder. Demerary en Essequibo een plan van bestuur hadden, dat nog steeds op uitwerking en toepassing vanwege Z.H. den Prins als Opperbewindhebber wachtte en dat het meest netelige punt van alle kwesties was het negervraagstuk of duidelijker gedetermineerd: de slavenhandel, waarover reeds lang de ethische en democratische richting den staf had gebroken. Hiervoor is er echter reeds met een enkel woord op gedoeld, dat de hoogste regeeringscolleges des lands de bestendiging van dezen onteerenden handel voor den bloei der kolonie nog onmisbaar achtten, zelfs uitbreiding er van wenschten te bevorderen, zoodat aan afschaffing niet gedacht werd.

En ten slotte was het op den voorgrond tredende materieele probleem dit: Uit welke bronnen moesten de onderstandsgelden, de zoo noodige subsidies bij wijze van koloniale leening worden geput en hoe moesten deze subsidies pondpondsgewijze over de respectievelijke onderdeelen worden verdeeld? Het officieele antwoord, dat op deze belangrijke vraag werd gegeven, was tevens een uiteenzetting van de kolonisatie-problemen van vroeger jaren in betrekking tot West-Indië en voor Holland een geschikte gelegenheid, om de andere gewesten er op te wijzen, dat ook zij proportioneel tot die subsidies moesten bijdragen. Van deze zijde was er tot dusverre steeds op gewezen, dat Holland en Zeeland uitsluitend deelden in de winsten en voordeelen van den handel op WestIndië, directe zoowel als indirecte, zoodat deze beide gewesten ook de lasten moesten dragen, een motiveering, die kant noch wal raakte en van weinig ethisch-koloniaal inzicht getuigde. Het antwoord dan, ontleend aan de Resoluties der Staten van Holland 1) laten we hier grootendeels textueel volgen om het in historicis belangrijke oordeel over deze koloniale paragraaf.

De subsidies dan waren onmisbaar voor de kolonie, zoo werd in deze resolutie betoogd, aangezien ,zo lang als de Compagnie bestondt, en de importante Colonien van den Staat van dezelve afhingen, dezelve ook moèst ondersteund worden in de Administratie van zaaken en bygesprongen met gereede penningen, wanneer haar Kas niet toereikte tot het onderhoud der Overzeesche Bezittingen; dat de Compagnie vooral schadeloos moest gesteld worden voor het gemis van de belastingen, door dezelve tot goedmaaking van haare onvermydelyke uitgaven op de Commercie gelegd

1) D.d. 16 Mei 1788 . 
en naderhand door den Souverain verminderd of zelfs provisioneel vernietigd.-

„Dat mitsdien hun Ed. Gr. Mogenden zich conformeerden met het Rapport der Heeren Gecommitteerden van Hun Hoogmogenden: ten dien effecte, dat ingeval by hun Hoog Mog. wierd geresolveerd, om voor Rekening van den Lande te doen maaken zoodanige Fortificatien op de Kusten van Guinea en Curaçao, St. Eustatius, St. Martin, Essequebo en Demerary, als men ten meesten nutte der Colonien zal vinden te behooren, als dan verder aan de West-Indische Compagnie, en wel ten spoedigsten, behoorde te worden geaccordeerd eene Subsidie van Vyf Tonnen Gouds, onder Guarantie van hun Hoog Mog. te negotieeren, ten einde de Compagnie daar door in staat te stellen tot gaandehouding van haar Bestuur ter verzorging van de Kust van Guinea en het noodzaaklyk onderhoud der andere Colonien onder haar Octroy. Dat tot betaaling der Intressen mitsgaders tot suppletie van het jaarlyks tekort ten behoeve van dezelfde Compagnie op den Staat van Oorlog worde gerepartitieerd eene jaarlyksche Subsidie van 250.000 Gulden voor de Jaaren MDCCLXXXVIII, MDCCLXXXIX, MDCCXC en MDCCXCI."

Om te ir wijzen, dat de voordeelen, voortvloeiende uit den handel met de Vest-Indische koloniën, niet enkel ten bate van Holland kwamen, betoogden de Ed. Groot Mogenden van dit gewest verder, dat, al mochten deze posten de regeeringen der andere gewesten wat veel en bezwaarlijk voorkomen, er verwacht mocht worden, ,dat aan den anderen kant zouden worden in aanmerking genomen de groote voordeelen, welke de West-Indische Colonien aan alle de Provincien verschaften en het niet langer kon gevergd worden, dat de last van de Overzeesche Bezittingen van den Staat genoegzaam alleen op Holland nederkwam. Dat mitsdien, zo de Bondgenooten zich tegen vermoeden zouden willen onttrekken van het helpen draagen der Lasten van deeze Etablissementen, waaraan Holland reeds zo veele Millioenen hadt te koste gelegd, het dan ook niet vreemd zou kunnen gevonden worden, dat hun Ed. Gr. Mog. door eene betere verzekering der Vrugten van de Colonien zich schadeloos stelden voor deeze importante uitgaven."

Dit voorstel van Hollands Staten vond ter vergadering van de Staten-Generaal wel instemming, vooral wat betrof de voorgedragen subsidies, zonder welke een vruchtbare koloniale politiek in de West niet langer mogelijk zou zijn, waarvan de meeste ter vergadering aanwezige leden zich dan ook wel overtuigd hielden. Maar nu was de groote moeilijkheid weer, hoe men op de beste 
wijze de geheel vervallen slavenhandel zou aanmoedigen, die eveneens voor de kolonie onontbeerlijk was en waarover Holland en Zeeland het nog maar steeds niet eens konden worden. Gevolg was uitstel van een definitief besluit, hoezeer dan ook Hun Hoogmogenden als de Edel Groot Mogenden der beide genoemde gewesten naar de eigen mededeeling van de Resolutie Generaal d.d. 27 Aug. 1788 ,overtuigd waren, dat die Handel op eene uitsteekende wijze behoorde aangemoedigd te worden als de grond van allen voorspoed der Colonien"!

Inmiddels hadden de planters en verschillende andere ingezetenen van de koloniën Berbice, Essequibo en Demerary ook weer niet stilgezeten om van hun kant door klaagschriften, protesten, adressen en requesten den hoogen nood van hun gebied en zijn inwoners in het licht te stellen. In de desbetreffende verzoekschriften, welke zij in den loop van dit jaar achtereenvolgens bij de bevoegde instanties hier te lande indienden, verzochten zij o.m. volledige vrijheid om door schepen van alle naties, welke er zich voor wilden leenen, van slaven te worden voorzien, zoolang althans als de West-Indische Compagnie of andere Nederlandsche slavenhalers in gebreke zouden blijven om te voldoen aan hun behoeften en den inhoud van het octrooi, door Hun Hoogmogenden aan die volksplantingen verleend. De desbetreffende stukken zijn ook in zooverre van beteekenis, dat men er de prijzen van het „slavenmateriaal" in verschillende perioden uit kan aflezen. Zoo werd voor een „werkbaare Veldneger", die eertijds met 500-600 gld. moest worden betaald, thans $800-1100$ gld. gevraagd en soms nog meer $\left.{ }^{1}\right)$.

(Slot volgt).

1) Een uitvoerig overzicht hiervan geven o.m. de Nieuwe Nederlandsche Jaarboeken van het jaar 1788, blz. 499-504. 